Article

\title{
Trade Credit Management Strategies in SMEs and the COVID-19 Pandemic-A Case of Poland
}

\author{
Grzegorz Zimon *(i) and Robert Dankiewicz
}

Department of Finance, Banking and Accountancy, The Faculty of Management, Rzeszow University of Technology, 35-959 Rzeszow, Poland; rdankiew@prz.edu.pl

* Correspondence: gzimon@prz.edu.pl; Tel.: +486-0397-9034

Received: 26 June 2020; Accepted: 27 July 2020; Published: 29 July 2020

\begin{abstract}
Every large or small enterprise needs to have financial liquidity and to be able to generate profits to develop. It is not important in which sector it operates, whether it is a private or public one, but profits and safety are two elements every enterprise is not able to function without. The low performance of these two measures can cause a number of difficulties for managers. To avoid this, leading companies, especially the smallest ones, should optimize the trade credit management policy. Most often, SMEs' (small and medium-sized enterprises) owners try to work together as part of a group purchasing organization, which positively affects trade credit management. The aim of the paper is to present the trade credit management strategy in Polish group purchasing organizations during the COVID-19 pandemic. The study uses data on the construction sector because it is one of the most important segments of the Polish economy, which is financed to a large extent with trade credit. The paper indicates the mechanisms whose applications allowed SMEs operating in purchasing groups to change trade credit management strategies in such a way that these units could operate calmly and safely in the market. These changes could be observed in purchasing goods with a large reserve, strictly controlling all receivables, switching to cash sales or limiting sales on long-term trade credit. The analysis showed that enterprises changed trade credit management strategies from moderately conservative to highly conservative.
\end{abstract}

Keywords: financial liquidity; trade credit; SMEs; group purchasing organizations; sustainability; Poland

\section{Introduction}

In modern economic conditions, one can observe a tendency of enterprises to pay for goods with some delay. Purchasing for a trade credit represents a significant proportion of total sales, but this share often varies from country to country. According to the data published in the ARTADIUS report in Western Europe, this percentage ranged from $25.4 \%$ in Switzerland to even $56.2 \%$ of total sales in Denmark [1]. In turn, according to the latest data, the percentage of total sales with a deferred payment in Eastern Europe was, on average, 67.2\%, while in Poland, 48.5\% [2]. What is more, one can notice a constant extension of payment deadlines for invoices, which is conducive to the development of credit purchases. However, such practices mean that a significant portion of the current assets of modern enterprises are in the form of receivables that arise from sales with a deferred payment. Therefore, any market turmoil that may adversely affect the financial situation of contractors and lead to their possible insolvency also poses a threat to the functioning of an enterprise, which, in its activity, grants trade credit to contractors. The literature indicates that trade credit makes the tightness of financial constraints change endogenously with the cash flow of those companies that are downstream. This means that credit links between enterprises generate very rich network effects through which shocks spread to the economy [3], which can be considered a kind of imperfection resulting from the use of trade credit. In order to minimize the risk of the negative impact of any market turbulence and 
problems on the contractors' side, it is necessary to develop an appropriate strategy for managing trade credit and properly safeguard the company's interests. There are many methods of managing trade credit, from the appropriate maneuvering of the payment terms offered, to the possibility of using trade credit insurance offered by insurance companies operating in the country.

Although offering a trade credit is often associated with risk, especially in the event of financial problems on the part of counterparties and, as a consequence, their insolvency, it is still an inseparable element of modern business operations. The use of the trade credit in business operations can bring many benefits to both the offering and the benefiting party. However, there are many disadvantages to using trade credit, such as opportunity cost, and it is important to consider factors that may affect the demand for trade credit and its terms. Therefore, proper management of trade credit is crucial for the survival of enterprises, without which, sustainable development is basically impossible. Trade credit management strategies have the key impact on the liquidity and profitability of enterprises, i.e., financial security and profitability. Today, without adequate financial security and profits, the sustainable development of SMEs (small and medium-sized enterprises) is impossible, especially during the COVID-19 pandemic.

Enterprises from the SMEs sector are defined as indispensable elements when it comes to economic growth and job creation, and thus, are a factor limiting unemployment [4]. In OECD countries, small and medium-sized enterprises generate between $50 \%$ and $60 \%$ of value added, and in developing countries, SMEs are responsible for around 33\% of GDP [5]. Enterprises belonging to the SMEs sector are extremely important for the national economy, so it is also relevant how the use of trade credit relates to their activities.

The aim of the paper is to analyze and evaluate the strategy of managing receivables from customers by enterprises from the SMEs sector that operate in group purchasing organizations. When researching commercial enterprises operating in the construction sector, which has the most bankruptcies in Poland, the receivables management strategies in the period before and during the pandemic were compared, as well as the impact of the COVID-19 pandemic on changing the approach of small and medium-sized enterprises to trade credit management was shown.

The study used data on the construction sector because it is one of the most important segments of both the European and Polish economy. It is known that small and medium-sized enterprises are the basis of every economy, and construction enterprises operating in Poland are mostly enterprises from the SME sector, therefore, their situation is of great importance for the overall economic situation of the country. In addition, this sector is financed, to a large extent, with the help of trade credit, which makes reflection on this topic even more important [6].

The study uses financial indicators developed on the basis of financial statements. The assessment and analysis of the trade credit management strategy by the said companies were made using basic descriptive statistics and a non-parametric Wilcoxon pairs order test. A model built on the basis of a multiple regression module was also constructed, in which Pearson's linear correlation analysis was used to examine the relationships between the quantitative variables studied.

The conducted research showed that the outbreak of the pandemic forced changes in trade credit management. These changes could be observed in purchasing goods with a large reserve, strictly controlling all receivables, switching to cash sales, limiting sales to long-term trade credit, as well as stopping sales at all costs. These changes point to even more cautious trade credit management during the COVID-19 pandemic of the surveyed enterprises. Therefore, these changes show that the trade credit management strategy is slowly changing from moderately conservative or conservative to clearly conservative.

\section{Literature Review}

Trade credit is the largest source of short-term business financing [7], as evidenced by the extensive use of this instrument in a market practice. In the literature, some attempts were made to identify the main determinants that had the impact on enterprises' decision to offer purchases on credit, 
even though this solution had some disadvantages. There are four main motives for using trade credit by enterprises. These include: financial motive, element of competitive strategy, reduction of transaction costs as well as quality control and signaling [8].

Referring to trade credit as part of a competitive strategy, it is worth paying attention to research that shows the impact of competition between suppliers on their willingness to grant trade credit. These studies show that the supplier responsible for most of the retailer's purchases is willing to finance the greater part of their sales to this retailer with trade credit [9]. What is more, N. Van Horen argues that the desire to compete is a very important driving force of the decision to grant trade credit, and this applies, in particular, to companies that still need to ensure good market position, and companies located in countries where the banking system is underdeveloped. On the other hand, monopolists sell fewer goods for credit [10]. It also turns out that trade credit can help mitigate price competition, especially in the case of financially limited enterprises [11].

One of the elements of trade credit management in enterprises is appropriate maneuvering of payment terms so as to encourage contractors, but also maintain an appropriate level of security. As the literature on the subject indicates, the traditional theories of extending trade credit show that both financial and non-financial motives may encourage the take-over role of financial intermediary [12]. However, it is indicated that management decisions related to an increase or a decrease of the trade credit offered and received, as well as decisions on possible changes during the recovery period, were affected by the company's financial results. Research shows that trade credit granted and received in the construction companies was directly correlated with return on equity and company size, and negatively correlated with return on assets [13]. In the light of the research available, the demand for trade credit is also influenced by internal factors such as available collateral, inventory turnover and period of payment of liabilities, and external ones, in particular the availability of banks or customer monopoly [14]. In turn, the research by D. Tsurutaa and H. Uchida showed that limiting the number of purchases reduces trade credit, and extending the maturity period increases it, and changes in the amount of actual transactions were the real driving force of trade credit during the crisis [15]. In addition, it was noted that large companies often served as financial intermediaries for their contractors who had less access to finance. Entities with financial restrictions use trade credit, especially during the financial crisis as an alternative financing method being a substitute for a bank loan [16]. In turn, in the light of R.R. Vaidya, companies with high profitability both grant and receive fewer trade credits, and companies with greater access to a bank loan offer their customers lower trade credit. On the other hand, companies with more bank loans receive more trade credits [17], which may be partly due to limited possibilities of obtaining financing from the bank. The literature also indicates that the supplier's bargaining power has a significant impact on the supply of trade credit. It is pointed out that suppliers with weaker bargaining power more often give their customers trade credit, and these loans have a longer period and constitute a larger share of goods sold. Important customers, in turn, extend payment periods beyond the terms offered by the supplier and generate overdue payments [18]. Among the determinants of the use of trade credit, the connection between trade credit supply and country risk was also noted. It turns out that in the pre-crisis period, commercial loans received increased when the state risk grew, while during the crisis, the supply of trade credit decreased along with the increase in the risk related to public debt [19]. Based on the empirical analysis of the impact of macroeconomic factors on late payments and arrears in the economy [20], it should be pointed out that in forecasting payment delays, it was particularly useful to observe the economic growth and monetary policy of the state, as these factors significantly affect the situation of enterprises, and therefore, also for late payment.

A special place in the literature on the subject is occupied by the research on the relationship between the use of trade credit and the results of business operations. The research conducted by A. Juan Grau and A. Reig on data from the period of the financial crisis showed that trade credit affected the profitability of an enterprise depending on the country and size, specifics, market power or reputation of the company [21]. Therefore, the level of profitability can be increased by investing 
in debt [22]. A similar relationship between the use of trade credit and profitability stems from S. Kumaraswamy and S. George's research, and the authors argue that effective debt management helps improve cash flow in an enterprise [23]. In turn, research on the Chinese market showed that the use of trade credit also had the significant impact on the sustainable development of enterprises, especially those with greater internal control capabilities [24]. In general, trade credit seems to increase the efficiency of enterprises, especially those that are more exposed to financial restrictions, i.e., smaller and younger enterprises, and thus contributes to reducing these restrictions [25]. This is due to the fact that it is often easier for small and young enterprises to obtain a trade credit than a bank loan, which means that they can continue to grow their business by overcoming their financial constraints.

Research shows that trade credit is of great significance in the structure of short-term liabilities of small and medium-sized enterprises, and is equally important for its users [26]. The scale of using trade credit in enterprises from the SMEs sector is affected by the life cycle of the company, and this impact depends on the size of the enterprise, and is stronger in young companies, although this relationship is non-linear throughout the life cycle [27]. Access to the insurers' offer is also important, which, in contrast to traditional insurance products offered in many markets for most of their participants [28], in the case of credit insurance, is sometimes limited, including company size, often excluding smaller interested entities from the group in advance [29]. At the same time, observations show that countries with a higher share of insured claims (in terms of value) show a higher level of trade than those where claim insurance is rare [30].

The attention should also be paid to the fact that trade credit proved to have a significant positive impact on the survival of the financial crisis of enterprises from the SMEs sector that had financial limitations [31]. The impact of using trade credit on profitability was also noted in the case of small and medium-sized enterprises [32-38]. By increasing investment in debt, profitability can be improved, and this effect is greater in the case of financially unrelated, larger and more liquid companies with variable demand and companies with a large market share [39]. When it comes to trade credit, the opportunity costs of commercial credit are also mentioned. It is pointed out that sometimes, the provider's opportunity cost may be less than the bank's cost, and lost profits from refusing a loan may be much higher. In turn, high interest on trade credit can mean a high opportunity cost of the seller's funds [40]. It is also pointed out that the opportunity cost of lending to large customers is rather positive and is growing rapidly in the face of the company's financial difficulties [41]. Due to the significant importance of enterprises from the SMEs sector for the national economy, it is extremely relevant for enterprises to learn how to properly manage trade credit, because improper management is a key obstacle to the survival and development of small and medium-sized enterprises [42].

Until now, trade credit was an excellent tool that allowed the company to attract new contractors and keep existing ones. The recipient, when receiving offers from suppliers where prices were similar, paid attention to the length of the trade credit offered. In general, SMEs could not compete with large enterprises, which were often market leaders. In order to improve their market position, SMEs began to cooperate, merge and operate within multi-stakeholder organizations. Purchasing groups were a great example of this type of organization. Group purchasing organizations (GPOs) are multi-stakeholder organizations whose main purpose is to organize joint purchases. They are created basically in every industry, however, most organizations of this type operate in the medical industry [43-50]. Working together allows taking advantage of economies of scale that reduce the cost of operating businesses [51,52]. The most important benefit for commercial enterprises is the possibility of obtaining low prices of the goods purchased and attractive trade credits. Low prices allow reducing the most important cost position for commercial enterprises, which is the value of goods sold at the purchase price and other cost items [53-59].

Most often, SMEs operating independently in the market benefited from classic trade credit management strategies. In the case of trade credit management, one can distinguish three classic strategies [60]: 
- A conservative strategy is a receivables management policy that aims to eliminate completely the risk of customer insolvency. It leads to the resignation from clients paying liabilities with a delay after a few prompts. This type of strategy is characterized by a short turnover period and a great deal of distrust towards new contractors, for whom cash sales are used for a long period of time, or a very short trade loan for a small amount.

- The aggressive strategy provides for granting trade credit to recipients with high solvency risk. The loan is granted without prior control of the recipients. An aggressive action increases the chance of gaining new customers and provides opportunities to increase sales. However, it may cause problems with the flow of receivables from customers.

- Moderate strategy is an indirect solution in the case of receivables management.

In the literature describing trade credit management strategies, there is no information about the limits for individual indicators describing the management strategies. The thresholds for individual indicators should be based on the industry, and the size of enterprises. The industry average could be a fairly good indicator. The results of individual companies in the article were compared to the industry average.

Entities operating in GPOs could modify classic strategies towards moderate ones. This was due to the scale effect, thanks to which they obtained an attractive trade credit from the manufacturer, which caused great opportunities in later offering loans to their customers, which led to a departure from the classic methods of trade credit management.

In the literature, one can find a number of studies on the analysis of credit management in various listed companies, in SMEs. However, there is a lack of studies showing how multi-stakeholder organizations such as GPOs affect trade credit management, especially during the COVID-19 pandemic.

Therefore, GPOs are a certain chance to gain new contractors; in the case of safe strategies, loosening the credit policy will lead to an increase in the level of receivables from recipients, and the benefit will be increased sales. If the trade credit offer will result in acquiring a new contractor who has so far cooperated with the competition, such activities should be assessed very positively; although, the company will bear the costs of financing the contractor.

\section{Methodology}

The research was conducted on a group of 54 trade companies operating in the construction sector. The enterprises that operate in the construction sector were deliberately selected for the study, because it was the reason for a high level of bankruptcy in Poland. The role of trade credit in such units is particularly important. The enterprises are SMEs operating in group purchasing organizations. GPOs are multi-stakeholder organizations where the trade credit management policy is the result of the scale effect achieved by the entire purchasing group. This allows SMEs to manage trade credit in a safe way. The years 2016-2018 were the research period, which was defined as the time before the COVID-19 pandemic, and the time during COVID-19 were the months March and April 2020.

The enterprises analyzed belong to the group of SMEs. In Poland, these enterprises are required to submit their financial statements to the National Court Register. The data for 2019 are not yet available. Moreover, in Poland, SMEs often submit incomplete financial reports, and their documentation is unavailable for months or even years because it is kept with judges. Outsiders do not have access to such reports. This situation makes it very difficult to obtain data from financial statements. In the literature, one can often find a lot of research and analysis on listed companies that publish their financial statements, in the case of SMEs, obtaining information in Poland is very complicated. The data for March and April 2020 were obtained directly from the analyzed enterprises from internal documentation prepared for the purposes of internal control. Most of the companies refused to cooperate. The COVID-19 pandemic hindered direct contact with the analyzed companies at the headquarters of the units.

Selected financial ratios based on which trade credit management policy was determined were used for the research. The analysis was conducted on a group of 54 enterprises operating in purchasing 
groups dealing with trade of heating and sanitary equipment. The largest purchasing groups in this sector were selected for the research; they have 92 units per day, April 2020. The share in total sales of the analyzed units in relation to all enterprises operating in GPOs operating in this industry. It amounts to: $2016-62 \%, 2017-62 \%$ and $2018-66 \%$.

The analysis should be treated as the first stage of research on trade credit management strategies during the COVID-19 pandemic. This is due to the fact that only two months from the time of the pandemic were analyzed. This is a very short period for broader conclusions, but the authors' goal was to present the mechanisms that SMEs' owners immediately used in the area of trade credit management to keep enterprises in the market and ensure their continuity of research. This is the first stage of research that will be verified by subsequent studies, where it will be analyzed throughout 2020 .

In the paper, the basic descriptive statistics to characterize the material was applied. Non-parametric Wilcoxon pairs order test was used in the work. It is an equivalent to Student's t-test for related variables. It is checked to see if there was a significant difference in the variables before and after the introduction of a given factor, which is the occurrence of the COVID-19 virus in the studies and the associated restrictions.

The null hypothesis $\left(\mathrm{H}_{0}\right)$ says that no changes took place.

In the model construction, the Pearson's linear correlation analysis was applied to examine the relationship between the quantitative variables studied, and the multiple regression module in Statistica 13.5 was used to construct the model itself. The normal distribution of residues was verified by means of the Pearson chi-square test.

\section{Results}

The first stage of the analysis was an assessment of trade credit management strategies in SMEs operating in GPOs before the COVID-19 pandemic. The table below presents the results of selected indicators on the basis of which the trade credit management strategy was determined. The details are presented in Table 1.

Table 1. Basic descriptive statistics of selected financial ratios.

\begin{tabular}{cccccccccc}
\hline & $(\bar{x} \pm \sigma)$ & $\mathbf{M e}$ & $\mathbf{M i n}$ & $\mathbf{M a x}$ & $\mathbf{Q}_{\mathbf{2 5}}$ & $\mathbf{Q}_{\mathbf{7 5}}$ & $\mathbf{V}_{\mathbf{z}}$ & $\mathbf{S}$ & $\mathbf{K}$ \\
\hline Liabilities turnover ratio in days & $(71 \pm 23)$ & 71 & 27 & 132 & 56 & 88 & 32.84 & 0.01 & 0.03 \\
Financial liquidity & $(2.61 \pm 1.09)$ & 2.30 & 1.20 & 6.5 & 1.80 & 3.10 & 41.78 & 1.46 & 2.73 \\
Quick liquidity ratio & $(0.41 \pm 0.08)$ & 0.40 & 0.40 & 1.00 & 0.40 & 0.40 & 20.04 & 7.28 & 53.0 \\
\hline
\end{tabular}

X-mean, $\sigma$-Standard deviation, Me-Median, Min-Minimum, Max-Maximum, Q25-Quartile 25, Q75-Quartile 75, Vz-Coefficient of variation, S-Skewness, K-Kurtosis. Source: Own research.

When analyzing the results of individual ratios included in Table 1 , it should be stated that the enterprises apply a conservative liquidity management policy. High results of individual ratios clearly indicate safe financial management of the enterprise.

Sector indices for the liquidity ratio in 2016-2018 ranged from 1.37-1.39. Therefore, the results presented in Table 1 are very high.

The most important financial liquidity ratio for the assessment of enterprises' safety is 2.61 . The lowest result for this ratio is 1.2 and it is a result that does not indicate the problems of enterprises with maintaining liquidity. This is a low result, but according to many authors, it is still within the safety limits [61-63]. In turn, the highest score of 6.5 clearly indicates excess liquidity. In every fourth company, the liquidity ratio was lower than from 1.8 and in every fourth, higher than 3.10 . On average, the liquidity ratio values deviate from the average by 1.09 .

Financial liquidity is closely related to trade credit management, which is why these results may indicate that in the case of trade credit management, enterprises in 2016-2018 also used secure management strategies.

When analyzing the results from Table 1, it should be stated that the coefficients of variation in all characteristics are high, which means a significant diversity of companies in terms of the variables 
studied. The distribution of the features is characterized by right-sided asymmetry, which means that in most companies, the ratios take values lower than the average. Kurtosis informs about the compliance of the distribution of the features examined with the normal distribution. In the case of the features, the platykurtic (positive) distribution is half, and therefore, more flattened than normal. The remaining ones have a leptokurtic (negative) distribution, so the ratios in these companies oscillate more around the average value.

The detailed information on the trade credit management strategy is provided in Table 2. It contains key information related to trade credit management. It also presents the results of selected indicators in the period before and during the COVID-19 pandemic in Poland, i.e., in March-April 2020.

Table 2. Basic descriptive statistics of ratios selected for comparison of the period before COVID-19 and during the COVID-19 pandemic.

\begin{tabular}{|c|c|c|c|c|c|c|c|c|}
\hline Ratio & $\overline{(x} \pm \sigma)$ & $\mathrm{Me}$ & Min & $\operatorname{Max}$ & $\mathbf{V}_{\mathbf{z}}$ & $S$ & $\mathbf{K}$ & $p$-Value \\
\hline $\begin{array}{l}\text { Receivables turnover ratio in days } \\
\text { (before COVID-19) }\end{array}$ & $(72 \pm 27)$ & 71 & 27 & 132 & 37.68 & 0.38 & -0.37 & \multirow[t]{2}{*}{$0.0000^{* * *}$} \\
\hline $\begin{array}{l}\text { Receivables turnover ratio [days] } \\
\text { (during COVID-19) }\end{array}$ & $(62 \pm 21)$ & 64 & 21 & 121 & 33.41 & -0.01 & 0.47 & \\
\hline $\begin{array}{l}\text { Share of short-term receivables in } \\
\text { current assets (before COVID-19) }\end{array}$ & $(0.45 \pm 0.10)$ & 0.47 & 0.23 & 0.70 & 20.46 & -0.51 & 0.97 & \multirow{2}{*}{$0.0000^{* * *}$} \\
\hline $\begin{array}{l}\text { Share of short-term receivables in } \\
\text { current assets (during COVID-19) }\end{array}$ & $(0.40 \pm 0.09)$ & 0.41 & 0.20 & 0.66 & 22.04 & -0.20 & 0.95 & \\
\hline Credit position (before COVID-19) & $(1.26 \pm 0.61)$ & 1.10 & 0.36 & 3.01 & 48.34 & 1.42 & 3.06 & \multirow{2}{*}{$0.0000^{* * *}$} \\
\hline Credit position (during COVID-19) & $(0.97 \pm 0.41)$ & 0.90 & 0.20 & 2.20 & 42.44 & 1.13 & 1.88 & \\
\hline $\begin{array}{l}\text { Share of short-term investments in } \\
\text { current assets (before COVID-19) }\end{array}$ & $(0.05 \pm 0.06)$ & 0.03 & 0.00 & 0.24 & 117.78 & 1.92 & 2.89 & \multirow[t]{2}{*}{$0.0000^{* * *}$} \\
\hline $\begin{array}{l}\text { Share of short-term investments in } \\
\text { current assets (during COVID-19) }\end{array}$ & $(0.12 \pm 0.07)$ & 0.10 & 0.01 & 0.31 & 60.84 & 1.22 & 1.23 & \\
\hline
\end{tabular}

Four main ratios related to the creation of trade credit management strategies were selected for the study-these are the receivables turnover ratio in days, the share of short-term receivables in current assets, credit position and the share of short-term investments in current assets. The ratios were measured before COVID-19 and during the pandemic. The test results are presented in Table 2 . The non-parametric Wilcoxon pairs order test was used for the tests, and it is equivalent to the Student's $t$ test for related variables. It was checked to see if there was a significant difference in the variables studied before and after the introduction of a given factor, which is the occurrence of the COVID-19 virus in the studies and the associated restrictions. The null hypothesis $\left(\mathrm{H}_{0}\right)$ says that no changes have taken place.

In all ratios examined, the changes were statistically significant, in each case, $p<\alpha(p=0.0000)$. Research shows that the receivables turnover ratio in days was higher before COVID-19; it averaged 72 days and during the course, it fell to 62 days. The medians were 71 and 64 days, respectively. Similarly, with the shares of receivables in current assets, they had a higher value before COVID-19-0.45 than after 0.40 . Medians were 0.47 and 0.41 , respectively.

The sector average for trade enterprises is about 40 days, so the results in the surveyed entities are high. The Industry Average Index brings together many different companies operating in different sectors of the economy. GPO allows one to obtain a favorable trade credit, which allows enterprises to extend trade credits to their recipients, which increases the turnover ratio of receivables from customers in the analyzed enterprises.

Figure 1 shows the distribution of enterprises for the receivables turnover ratio in days. 


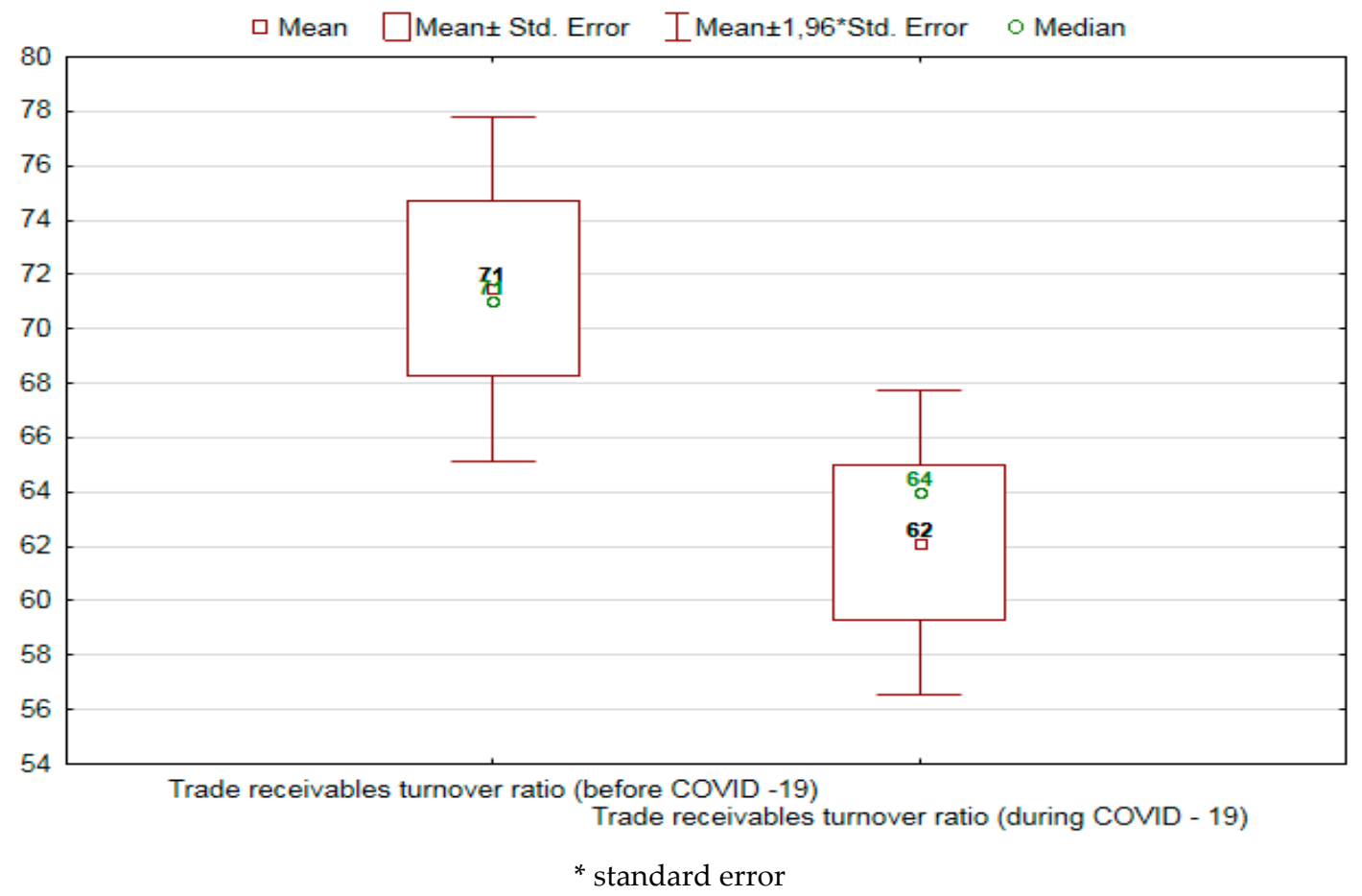

Figure 1. Receivables turnover ratio before and during the COVID-19 pandemic in the companies surveyed. Source: Own research.

Figure 2 shows the distribution of enterprises for the share of short-term receivables in current assets.

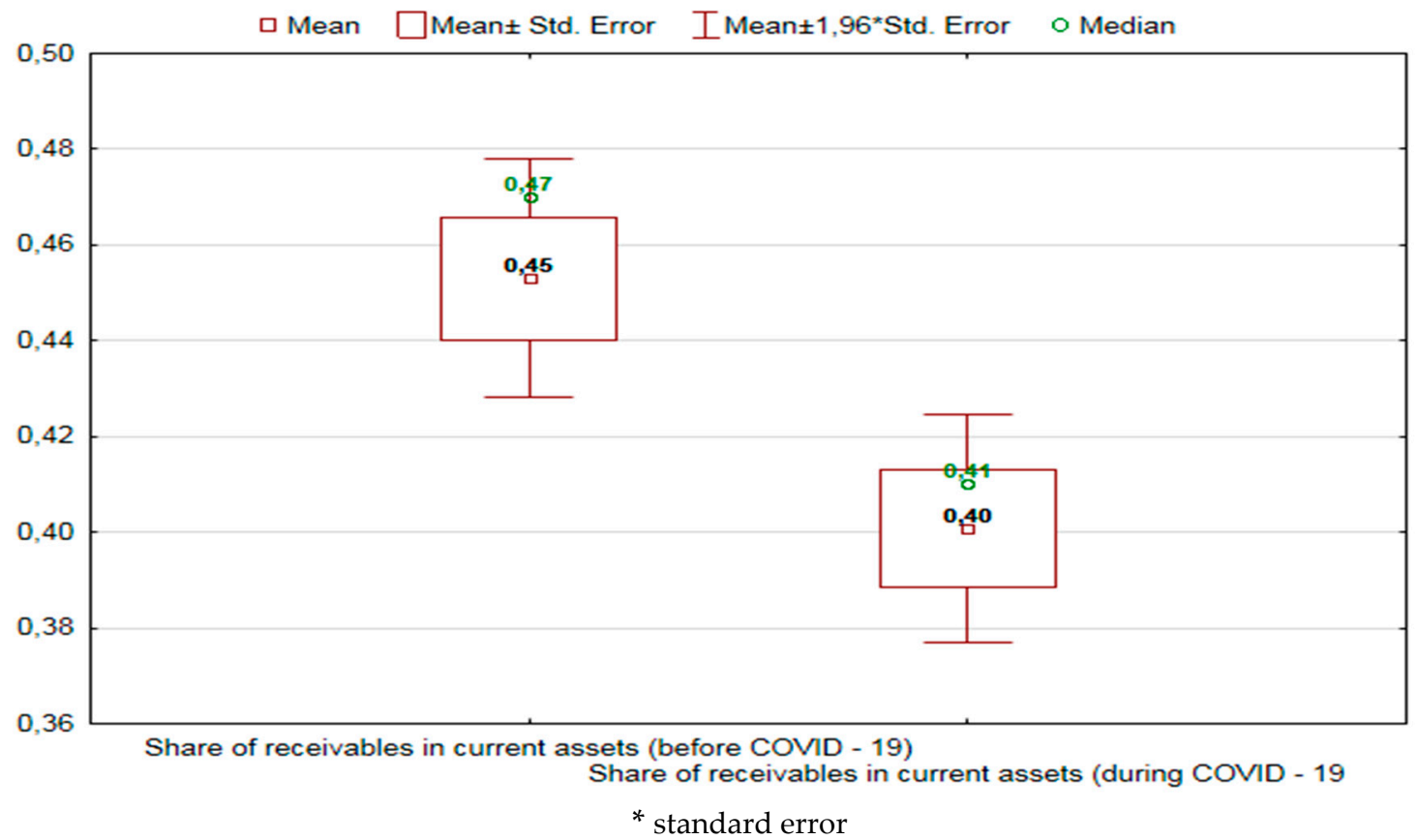

Figure 2. Shares of receivables in current assets during COVID-19 pandemic in the companies surveyed. Source: Own research.

The credit position is the ratio of receivables from customers to liabilities to suppliers. A score above 1 means that the enterprise is a lender, and a score below 1 means that the enterprise is a borrower. 
In the case of credit position, the ratio takes higher values before COVID-19-1.26 than during its duration 0.97 . The medians are 1.1 and 0.9 , respectively. The details in graphic form are presented in Figure 3.

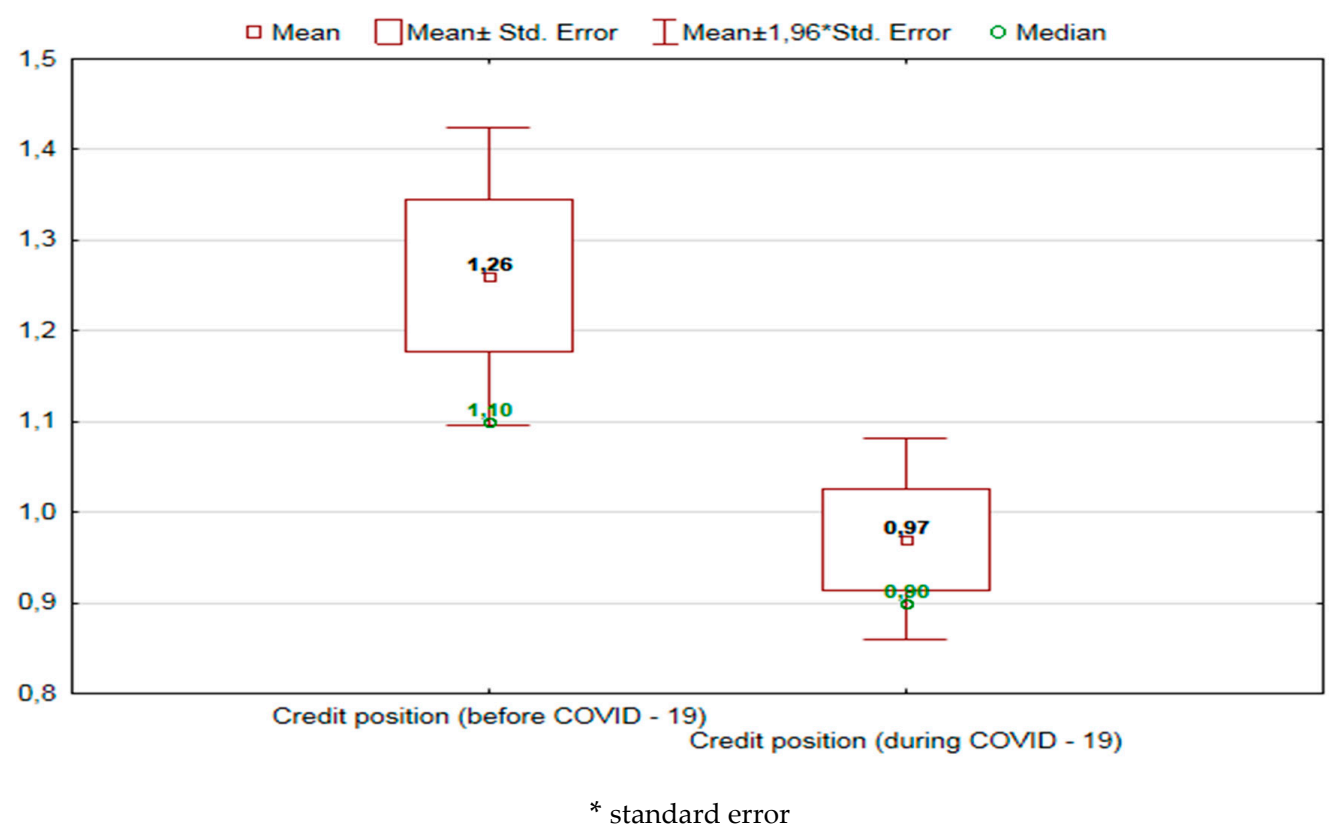

Figure 3. Credit position before and during the COVID-19 pandemic in the companies surveyed. Source: Own research.

In turn, when analyzing the share of short-term investments in current assets, the results before COVID-19 are lower and amount to 0.05 on average, while the level increased to 0.12 . Medians were 0.03 and 0.1 , respectively. The details are presented in Figure 4.

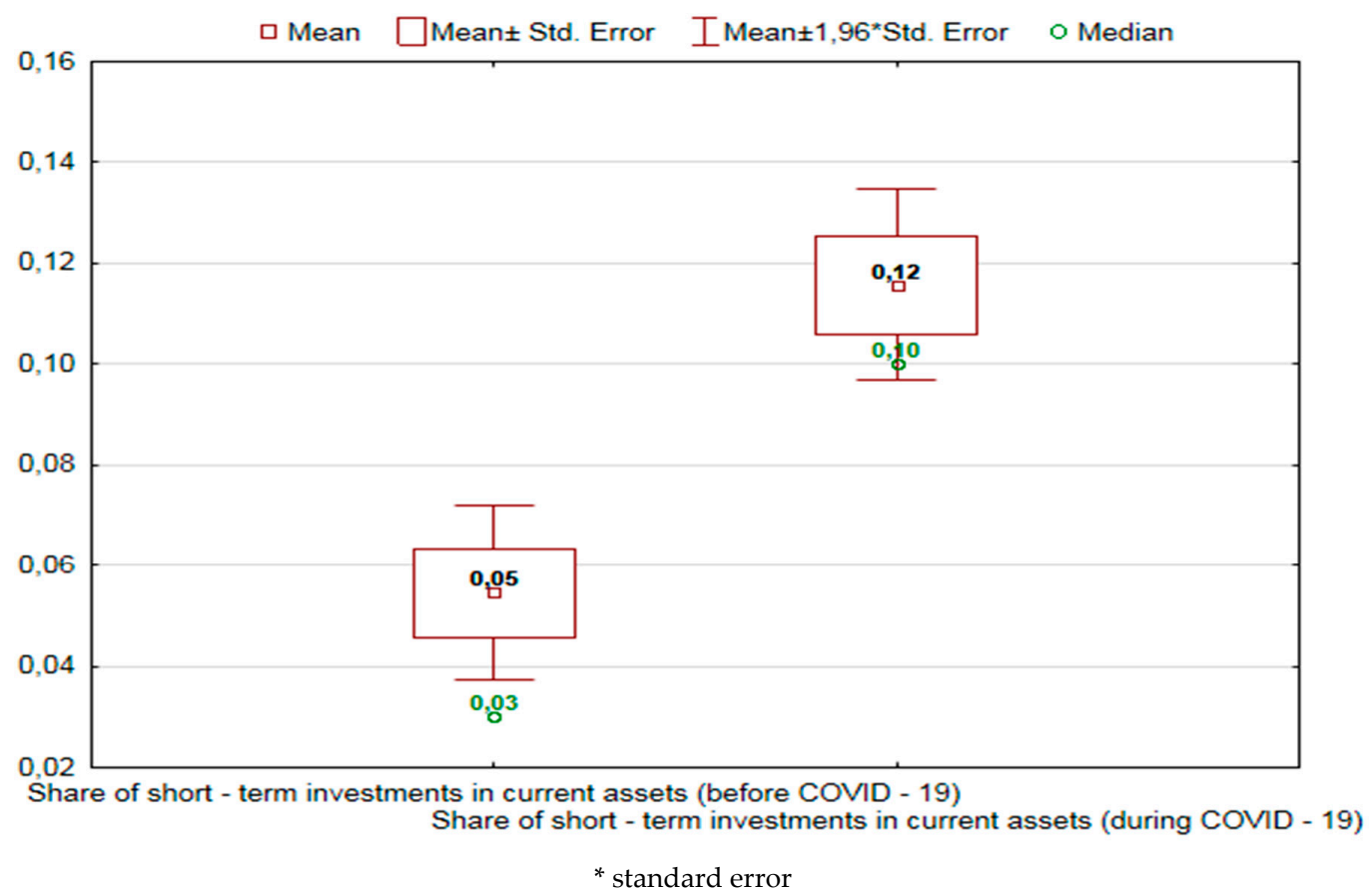

Figure 4. Investments before and during the COVID-19 pandemic in the companies surveyed. Source: Own research. 
The bag plot clearly shows that there are various types of companies; most of them accumulate in the middle of the bag, but there are a few outliers, where investments before and after were high and both before and after were low (such cases are marked with asterisks on the plot).

The bag plot shows that the dispersion of share of short-term investments in current assets during COVID-19 increased from 0 to 0.24 before to 0.31 during COVID-19 (Figure 5).

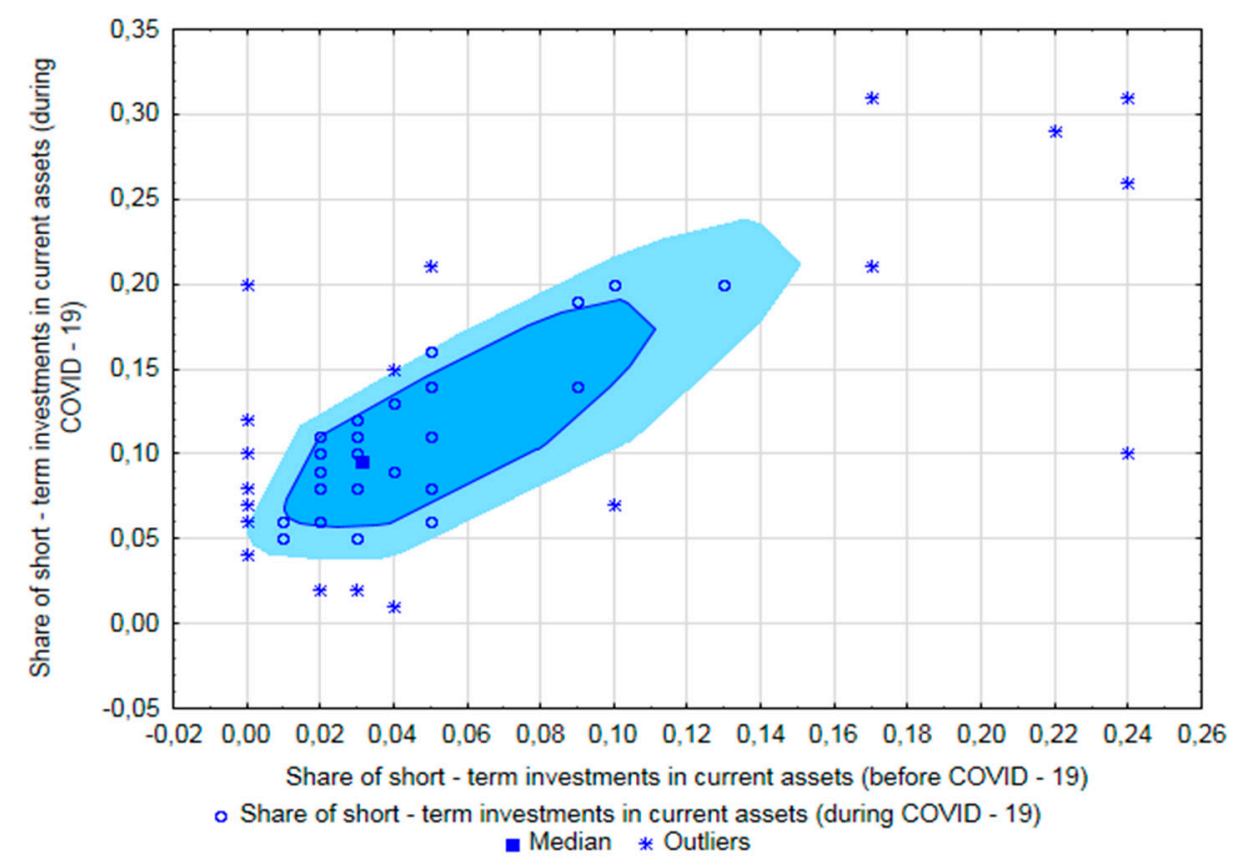

Figure 5. Bag plot-investments before and during the COVID-19 pandemic. Source: Own research.

Then, the relationship between financial liquidity and the ratios adopted for testing was checked: credit position, receivables turnover in days, inventory turnover in days and payables to suppliers in days.

\section{Structure of an Econometric Model}

Liquidity was adopted as the dependent variable Y (days)

The independent variables were: receivables rotation (days)

- liabilities rotation (days)

- inventory rotation (days)

- credit position.

Correlation coefficients are presented in Table 3. The largest relationship with financial liquidity has a credit position. The correlation coefficient was 0.82 and it is very high, positive and directly proportional, and along with a growth in the credit position, the liquidity increases. At $82 \%$, the credit position models liquidity.

Table 3. Correlation coefficients between liquidity and selected features.

\begin{tabular}{ccccc}
\hline & Credit Position & Liabilities & Receivables & Inventories \\
\hline Financial Liquidity & 0.82 & -0.59 & 0.23 & 0.09 \\
$p$-value & 0.0000 & 0.0000 & 0.0930 & 0.5250 \\
\hline
\end{tabular}

Source: Own research

The second relationship, as for the strength, is the relationship between liquidity and liabilities to suppliers are presented in Figure 6. The relationship is high (-0.59) except that the relationship is 
negative inversely proportional. Liquidity decreases as liabilities increase. In 59\%, liabilities model financial liquidity.

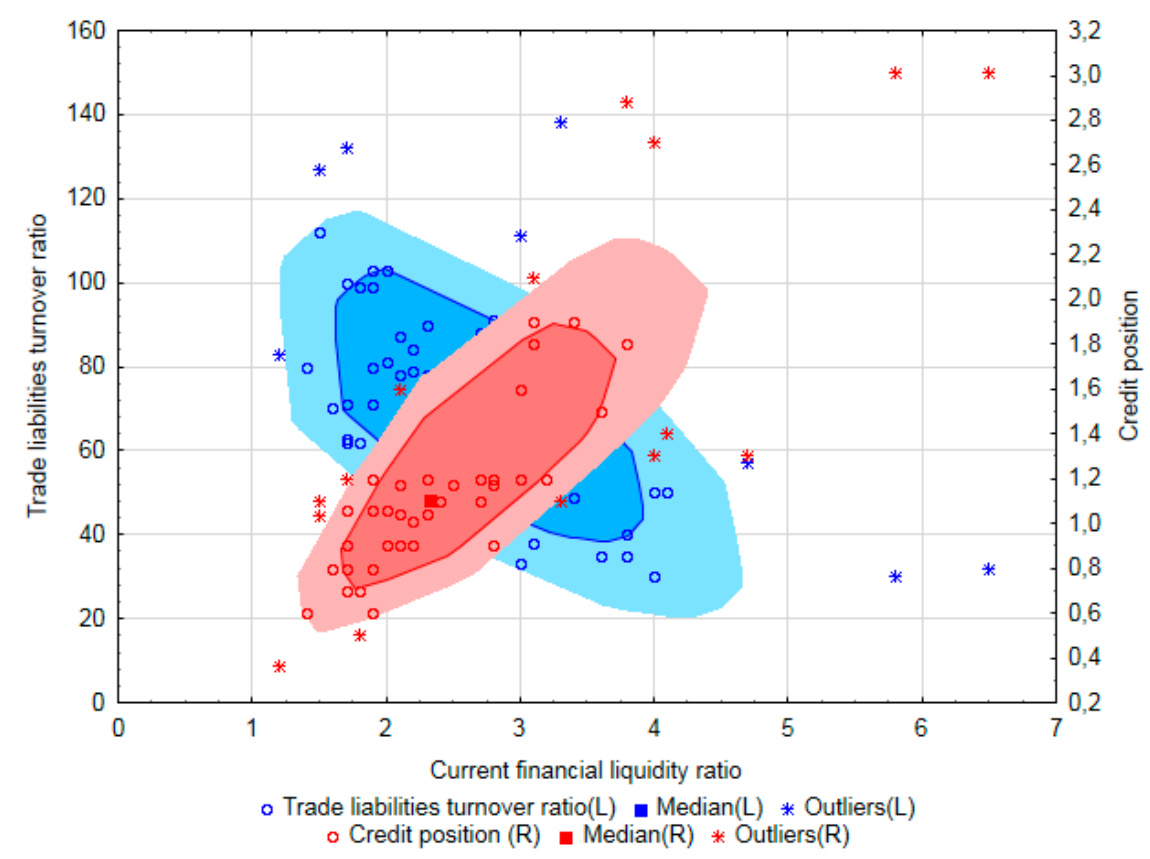

Figure 6. Relationship between liquidity and credit position and liabilities. Source: Own research.

Before the regression equation, for the readability of the results, the basic results data are presented in Table 4.

Table 4. The results of the econometric model estimation.

\begin{tabular}{ccccccc}
\hline $\mathbf{R}=\mathbf{0 . 8 9} \mathbf{R}^{\mathbf{2}}=\mathbf{0 . 8 0}$ Correct. $\mathbf{R}^{\mathbf{2}}=\mathbf{0 . 8 0}, \mathbf{F}(\mathbf{3 . 4 9 )}=\mathbf{6 8 . 2 6 7}$ & $\boldsymbol{p}<\mathbf{0 . 0 0 0 0 0}$ Std. Estim. Error: $\mathbf{0 . 4 9 4 2 6}$ \\
\hline & $\mathbf{B}$ & Std. error from $\mathbf{b}$ & $\mathbf{b}$ & Std. error from $\mathbf{b}$ & $\mathbf{t}(\mathbf{4 9 )}$ & $\boldsymbol{p}$ \\
Constant & & & 0.04 & 0.44 & 0.10 & 0.9200 \\
Credit & 0.77 & 0.08 & 1.37 & 0.14 & 9.77 & 0.0000 \\
position & & 0.07 & 0.02 & 0.00 & 5.58 & 0.0000 \\
Inventory & 0.37 & 0.08 & -0.01 & 0.00 & -3.16 & 0.0027 \\
Liabilities & -0.25 & $*$ b standard error. Source: Own research.
\end{tabular}

After testing, the following model was obtained:

Three variables entered the model, which were marked as:

$\mathrm{X}_{1}$ - credit position

$\mathrm{X}_{2}$-inventory rotation

$\mathrm{X}_{3}$-liabilities rotation.

Variable numbers were assigned as features in the order appearing in the model (depending on their importance):

$$
\begin{gathered}
Y=0.04+1.37 X_{1}+0.02 X_{2}-0.01 X_{3} \\
(0.443)(0.140)(0.004)(0.004)
\end{gathered}
$$

The model is adjusted to the data in $80 \%\left(\mathrm{R}^{2}=0.80\right)$, so the adjustment is very high. In order for the model to be properly constructed, the rest of the model should be characterized primarily by normal distribution. Therefore, the null hypothesis $\left(\mathrm{H}_{0}\right)$ was assumed, which said that the rest of the model was characterized by a normal distribution to the alternative hypothesis $\left(\mathrm{H}_{1}\right)$ and that the rest of the model did not have a normal distribution. A significance level of $\alpha=0.05$ was adopted for the study. The analyses show that $p>\alpha(p=0.40218)$, and therefore, there are no grounds to reject the 
null hypothesis with a normal distribution of residues. It is worth noting that if the credit position increases by one unit, the liquidity will grow by 1.37 (assuming that the remaining independent variables maintain constant values).

The inventory and payables turnover towards suppliers is related to financial liquidity, less with trade credit, therefore, a detailed interpretation of the results will be omitted. In the case of broader research with data at the end of 2020, it will be worth introducing these ratios, in terms of analysis of building trade credit management strategies.

In order to broaden the assessment of the trade credit management strategy, a supplier liability management analysis was performed. The detailed results are presented in Table 5.

Table 5. Basic indicators of the share of liabilities to suppliers selected for comparison of the period before COVID-19 and during the COVID-19 pandemic.

\begin{tabular}{|c|c|c|c|c|c|c|c|c|}
\hline Ratio & $(\bar{x} \pm \sigma)$ & $\mathrm{Me}$ & Min & Max & $\mathbf{V}_{\mathbf{z}}$ & $S$ & $\mathbf{K}$ & $p$-Value \\
\hline $\begin{array}{c}\text { Share of trade liabilities in } \\
\text { liabilities and provision for } \\
\text { liabilities (\%)(before COVID -19) }\end{array}$ & $\begin{array}{l}(0.9164 \pm \\
0.17)\end{array}$ & 0.98 & 0.24 & 0.99 & 18.39 & -3.25 & 10.13 & $0.0012^{* * *}$ \\
\hline $\begin{array}{l}\text { Share of trade liabilitiesin liabilities } \\
\text { and provisionfor liabilities } \\
(\%)(\text { during COVID-19) }\end{array}$ & $\begin{array}{l}(0.9160 \pm \\
0.19)\end{array}$ & 0.98 & 0.17 & 0.99 & 20.62 & -3.16 & 8.89 & \multirow{3}{*}{$0.0000^{* * *}$} \\
\hline $\begin{array}{l}\text { Share of trade liabilities in total } \\
\text { liabilities (before COVID-19) }\end{array}$ & $\begin{array}{c}(0.4398 \pm \\
0.17)\end{array}$ & 0.48 & 0.04 & 0.82 & 39.44 & -0.38 & -0.27 & \\
\hline $\begin{array}{l}\text { Share of trade liabilities in total } \\
\text { liabilities (during COVID-19) }\end{array}$ & $\begin{array}{c}(0.4562 \pm \\
0.17)\end{array}$ & 0.49 & 0.04 & 0.82 & 37.86 & -0.40 & -0.30 & \\
\hline
\end{tabular}

The results defining the share of liabilities towards suppliers in the structure of liabilities and total liabilities are at a similar level during COVID-19 and before COVID-19. There is a slight increase of 0.01 for the share of liabilities. The lack of a clear decrease in liabilities to suppliers may be good news, as it proves still that SMEs operating in purchasing groups use the cheapest source of financing their activities, which is a trade credit. A decrease in the share of liabilities to suppliers would suggest accelerating the payment of liabilities to suppliers, and such a situation does not appear.

\section{Discussion and Conclusions}

The COVID-19 outbreak forced changes in merchant credit management. In SMEs operating in group purchasing organizations, the first step was to buy goods and materials with a lot of reserve. This was related to the fear of the occurrence of downtime in the work of factories supplying goods to the purchasing groups. This was the correct assumption as several producer factories are located in Germany, Italy, the Czech Republic and Spain, and it was from two factories in Italy where supply was suspended for a period of three weeks of delivery.

The next changes that could be observed were already closely related to the management of receivables from customers. The principle of strict aggressive control of all receivables and the transition to cash sales as much as possible was adopted in SMEs. Sales with long trade credit were strongly limited, especially for new customers. Only strategic recipients maintained trade credit at the same level.

Another change in the strategy of managing receivables from customers was the policy of "respecting inventory". The sales were discontinued at any price, which was connected with the offer of additional discounts or extending the trade credit. It turned out that without such an offer, the level of sales did not change.

The changes presented clearly point to an even more cautious trade credit management policy during COVID-19. No wonder SMEs in Poland, taught by the crisis in 2008, are afraid of payment gridlocks. It can be concluded that, during the COVID-19 pandemic, a movement towards a highly conservative strategy was observed under the safe strategies that have so far been used in the analyzed enterprises. 
These activities are confirmed by the results presented earlier. The actions taken in limiting the sale of goods with long trade credit and detailed control of receivables, resulted in a decrease in receivables turnover in days, and a decrease in the share of receivables from customers in the structure of current assets. The decrease in receivables from customers and the maintenance of the previous level of liabilities resulted in a decrease in the level of credit position ratio. There was also a growth in the level of short-term investments, caused by an increase in the level of cash resulting from pressures on cash sales. The relationship between financial liquidity and credit position was observed. A decline in credit position causes a decrease in financial liquidity. The share of liabilities to suppliers in the structure of total liabilities does not increase, which should be assessed positively. During the COVID-19 pandemic, companies try to collect their receivables as quickly as possible, therefore, maintaining the level of liabilities towards suppliers at the same level proves a safe corporate management policy. They were not forced to settle their liabilities quickly. When analyzing the structure of current assets during COVID-19 in March and April 2020, a clear increase in cash, a decrease in receivables and a slight growth in inventories can be seen compared to 2016-2018. As a result of enhanced control of receivables, there was a decrease in the turnover of receivables from customers.

The summary clearly shows that the trade credit management strategy is slowly changing from moderately conservative or conservative to a clearly conservative one. The following months will show whether this change is permanent or will only relate to the period in which the incidence in Poland and various types of quarantine imposed by the Polish government on society were recorded. These studies are an introduction to the wider research that will be carried out in the future on the basis of data for the entire year of 2020 .

Author Contributions: Conceptualization, G.Z..; methodology, G.Z. and R.D.; formal analysis, G.Z. and R.D.; investigation, G.Z. and R.D.; resources, G.Z. and R.D.; data curation, G.Z. and R.D.; writing-original draft preparation, G.Z. and R.D.; writing-review and editing, G.Z. and R.D.; visualization, G.Z. and R.D. All authors have read and agreed to the published version of the manuscript.

Funding: This research received no external funding.

Conflicts of Interest: The authors declare no conflict of interest.

\section{References}

1. ATRADIUS. Western Europe: An increase in past due B2B invoices. Atradius Payment Practices Barometer. 2018, p. 3. Available online: https://group.atradius.com/publications/payment-practices-barometer-westerneurope-2018.html (accessed on 22 May 2020).

2. ATRADIUS. Poland: Higher Insolvency Levels Ahead. Atradius Payment Practices Barometer. 2019. Available online: https:/group.atradius.com/publications/payment-practices-barometer-poland-2019.html (accessed on 22 May 2020).

3. Altinoglu, L. The origins of aggregate fluctuations in a credit network economy. In Finance and Economics Discussion Series 2018-031; Board of Governors of the Federal Reserve System: Washington, DC, USA, 2018; pp. 1-46. [CrossRef]

4. Agostino, M.; Trivieri, F. Does Trade Credit Affect Technical Efficiency? Empirical Evidence from Italian Manufacturing SMEs. J. Small Bus. Manag. 2019, 57, 576-592. [CrossRef]

5. Nowakowska-Grunt, J.; Kowalczyk, A.; Wojtaszek, H. Prospects for development of the SME sector in Poland in the, field of government's policy towards small and medium-sized enterprises. World Sci. News 2018, 103, 235.

6. European Commission. European Construction Sector Observatory; Country Profile Poland; European Commission: Brussels, Belgium, 2018; pp. 1-29.

7. Petersen, M.; Rajan, R. Trade credit: Theories and evidence. Rev. Financ. Stud. 1997, 10, 661-691. [CrossRef]

8. Ciżkowicz-Pękała, M. Trade credit: A benefit to get, a "must" to give? Motives behind trade credit use in Poland. Financ. Internet Q. E-Finans. 2017, 14, 55-56. [CrossRef]

9. Chod, J.; Lyandres, E.; Alex Yang, S. Trade Credit and Supplier Competition. J. Financ. Econ. Elsevier 2019, 131, 484-505. [CrossRef] 
10. Van Horen, N. Trade Credit as a Competitiveness Tool; Evidence from Developing Countries; MPRA Paper No. 2792; The University of Amsterdam: Amsterdam, The Netherlands, 2004; pp. 1-25.

11. Peura, H.; Yang, S.A.; Lai, G. Trade Credit in Competition: A Horizontal Benefit. Manuf. Serv. Oper. Manag. 2017, 19, 263-289. [CrossRef]

12. Delannay, A.F.; Weill, L. The Determinants of Trade Credit in Transition Countries. Econ. Chang. Restruct. 2004, 37, 173-193. [CrossRef]

13. Birbuta-Misu, N. Analysis of factors influencing managerial decision to use trade credit in construction sector. Econ. Res. Ekonomska Istraživanja 2019, 31, 1903-1922. [CrossRef]

14. Yazdinejad, E.A.; Jokar, H. Discovering determinants of trade credit demand: Evidence from top managers insight. Cogent Econ. Financ. 2019, 7, 1-15. [CrossRef]

15. Tsurutaa, D.; Uchida, H. The real driver of trade credit. Pac. Basin Financ. J. 2019, 57, 1-23. [CrossRef]

16. Santos, J.; Silva, A. The Determinants of Trade Credit: A Study of Portuguese Industrial Companies. Int. J. Financ. Res. 2014, 5, 128-138. [CrossRef]

17. Fabbri, D.; Klapper, L.F. Bargaining power and trade credit. J. Corp. Financ. Elsevier 2016, 41, 66-80. [CrossRef]

18. Vaidya, R.R. The Determinants of Trade Credit: Evidence from Indian Manufacturing Firms. Mod. Econ. 2011, 2, 707-716. [CrossRef]

19. Cantero Sáiz, M.; Sanfilippo Azofra, S.; Torre Olmo, B.; López Gutiérrez, C. Trade credit, sovereign risk and monetary policy in Europe. Int. Rev. Econ. Financ. 2017, 52, 39-54. [CrossRef]

20. Woźniak, D.; Sokołowska-Woźniak, J.; Jankowiak, B.; Cwynar, A.; Cwynar, W.; Ostrowska-Dankiewicz, A.; Dankiewicz, R. Trade Credit in Polish Companies. An Empirical Analysis of Macroeconomic Factors Influencing Payment Delays. In Business and Non-profit Organizations Facing Increased Competition and Growing Customers' Demands, Proceedings of the 17th Conference of Scientists and Business People, Tomaszowice, Poland, 18-19 June 2018; Nalepka, A., Ujwary-Gil, A., Eds.; Foundation for the Dissemination of Knowledge and Science "Cognitione": Nowy Targ, Poland, 2018; Volume 17, pp. 627-644.

21. Juan Grau, A.; Reig, A. Trade credit and determinants of profitability in Europe. The case of the T agri-food industry. Int. Bus. Rev. 2018, 27, 947-957. [CrossRef]

22. Abuhommous, A.A.A. The Impact of Offering Trade Credit on Firms' Profitability. J. Corp. Account. Financ. 2017, 28, 29-40. [CrossRef]

23. Kumaraswamy, S.; George, S. Trade credit management and firm profitability of Saudi manufacturing firms. Pol. J. Manag. Stud. 2019, 20, 243-253.

24. Huang, L.; Ying, Q.; Yang, S.; Hassan, H. Trade Credit Financing and Sustainable Growth of Firms: Empirical Evidence from China. Sustainability 2019, 11, 1032. [CrossRef]

25. OECD. Enhancing the Contributions of SMEs in a Global and Digitalised Economy. 2017, p. 6. Available online: https://www.oecd.org/industry/C-MIN-2017-8-EN.pdf (accessed on 22 May 2020).

26. Ziętek-Kwaśniewska, K. The significance of trade credit for micro and small enterprises. Finans. Rynki Finans. Ubezp. 2017, 5, 257-266. [CrossRef]

27. Canto-Cuevas, F.J.; Palacín-Sánchez, M.J.; Di Pietro, F. Trade Credit as a Sustainable Resource during an SME's Life Cycle. Sustainability 2019, 11, 670. [CrossRef]

28. Dankiewicz, R. Ubezpieczenie transakcji jednostkowych jako alternatywa względem klasycznych ubezpieczeń kredytu kupieckiego. In Ubezpieczenia; Wyzwania, R., Kwiecień, I., Kowalczyk-Rólczyńska, P., Eds.; C.H. Beck: Warszawa, Poland, 2019; pp. 215-228.

29. Dankiewicz, R. Ubezpieczenia kredytów eksportowych jako narzędzia wspierające handel międzynarodowy. Ann. Univ. Mariae Curie Skłodowska Sectio H Oecon. 2016, 50, 49-58. [CrossRef]

30. Dankiewicz, R.; Simionescu, M. The Insurance Market in Romania: A Macroeconomic and a Microeconomic Approach. Transform. Bus. Econ. 2020, 19, 248-261.

31. McGuinness, G.; Hogan, T.; Powell, R. European trade credit use and SME survival. J. Corp. Financ. 2018, 49, 81-103. [CrossRef]

32. Zimon, G. Influence of group purchasing organizations on financial situation of Polish SMEs. Oeconomia Copernic. 2018, 9, 87-104. [CrossRef]

33. Degryse, H.; Matthews, K.; Zhaoca, T. SMEs and access to bank credit: Evidence on the regional propagation of the financial crisis in the UK. J. Financ. Stab. 2018, 38, 53-70. [CrossRef] 
34. Wilner, B.S. The exploitation of relationship in financial distress: The case of trade credit. J. Financ. 2000, 55, 153-178. [CrossRef]

35. Bougheasa, S.; Mateut, S.; Mizen, P. Corporate trade credit and inventories: New evidence of a trade-off from accounts payable and receivable. J. Bank. Financ. 2009, 33, 300-307. [CrossRef]

36. Zimon, D. Impact of the implementation of quality management system on operating cost for small and medium-sized business organizations affiliated to a purchasing group. Int. J. Qual. Res. 2015, 9, 551-564.

37. Jain, N. Monitoring costs and trade credit. Q. Rev. Econ. Financ. 2001, 41, 89-110. [CrossRef]

38. Giannetti, M.; Burkart, M.; Ellingsen, T. What You Sell Is What You Lend? Explaining Trade Credit Contracts. Rev. Financ. Stud. 2011, 24, 1261-1298. [CrossRef]

39. Murfin, J.; Njoroge, K. The Implicit Costs of Trade Credit Borrowing by Large Firms. Rev. Financ. Stud. Soc. Financ. Stud. 2015, 28, 112-145. [CrossRef]

40. Cunat, V. Trade credit: Suppliers as debt collectors and insurance providers. Rev. Financ. Stud. 2007, 20, 491-527. [CrossRef]

41. Martínez-Sola, C.; García-Teruel, P.; Martínez-Solano, P. Trade credit and SME profitability. Small Bus. Econ. Springer 2014, 42, 561-577. [CrossRef]

42. Otto, W.H. Management of trade credit by small and medium-sized enterprises. J. Econ. Financ. Sci. 2018, 11, 1-8. [CrossRef]

43. Zimon, D.; Zimon, G. The impact of implementation of standardized quality management systems on management of liabilities in group purchasing organizations. Qual. Innov. Prosper. 2019, 23, 60-73. [CrossRef]

44. Essig, M. Purchasing consortia as symbiotic relationships: Developing the concept of "consortium sourcing". Eur. J. Purch. Supply Manag. 2000, 6, 13-22. [CrossRef]

45. Cowan, A.E.; Clark, S.J.; Gordon, J.L.; Bok, K.; Shen, A.K. Vaccine purchasing groups in the United States: An overview of their policies and practices. Vaccine 2016, 34, 5060-5065. [CrossRef]

46. Nollet, J.; Beaulieu, M. Should an organization join a purchasing group? Supply Chain Manag. 2005, 10, 11-17. [CrossRef]

47. Marvel, H.P.; Yang, H. Group purchasing, nonlinear tariffs, and oligopoly. Int. J. Ind. Organ. 2008, 26, 1090-1105. [CrossRef]

48. Quayle, M. Purchasing in small firms. Eur. J. Purch. Supply Manag. 2002, 8, 151-159. [CrossRef]

49. Burns, L.R.; Lee, J.A. Hospital purchasing alliances: Utilization, services, and performance. Health Care Manag. Rev. 2008, 33, 203-215. [CrossRef] [PubMed]

50. Tella, E.; Virolainen, V.M. Motives behind purchasing consortia. Int. J. Prod. Econ. 2005, 93-94, 161-168. [CrossRef]

51. Polychronakis, Y.; Syntetos, A. 'Soft' supplier management related issues: An empirical investigation. Int. J. Prod. Econ. 2007, 106, 431-449. [CrossRef]

52. Z Blair, R.D.; Durrance, P. Group Purchasing Organizations, Monopsony and Antitrust Policy. Manag. Decis. Econ. 2014, 35, 433-443. [CrossRef]

53. Zimon, G. Organization of Transport in a Commercial Enterprise Operating in a Branch Purchasing Group. Estudios Economia Aplicada 2018, 36, 811-824. [CrossRef]

54. Schotanus, F.; Telgen, J. Developing a typology of organizational forms of cooperative purchasing. J. Purch. Supply Manag. 2007, 13, 53-68. [CrossRef]

55. Sandberg, E.; Mena, C. Exploring strategic strengths and weakness of retail purchasing groups. Int. Rev. Retail. Distrib. Consum. Res. 2015, 25, 276-297.

56. Faes, W.; Matthyssens, P.; Vandenbempt, K. The pursuit of global purchasing synergy. Ind. Mark. Manag. 2000, 29, 539-553. [CrossRef]

57. Hu, Q.; Schwarz, L.B.; Uhan, N.A. The impact of group purchasing organizations on healthcare-product supply chains. Manuf. Serv. Oper. Manag. 2012, 14,7-23. [CrossRef]

58. Bals, L.; Laine, J.; Mugurusi, G. Evolving purchasing and supply organizations: A contingency model for structural alternatives. J. Purch. Supply Manag. 2018, 24, 41-58. [CrossRef]

59. Luzzini, D.; Longoni, A.; Moretto, A.; Caniato, F.; Brun, A. Organizing IT purchases: Evidence from a global study. J. Purch. Supply Manag. 2014, 20, 143-155. [CrossRef]

60. Zimon, G. Model of the branch purchasing group in the chemical industry. Przem. Chem. 2018, 97, 1808-1810. 
61. Higgins, R.C. Analysis for Financial Management; McGraw-Hill: New York, NY, USA, 2012.

62. Shin, J.K.; Siegel, J.G. Modern Management $\mathcal{E}$ Analysis; Barrons: New York, NY, USA, 2009.

63. Sagner, J.S. Working Capital Management; Wiley: Hoboken, NJ, USA, 2014.

(C) 2020 by the authors. Licensee MDPI, Basel, Switzerland. This article is an open access article distributed under the terms and conditions of the Creative Commons Attribution (CC BY) license (http://creativecommons.org/licenses/by/4.0/). 